\title{
Influence of plant phenostage and ploidy level on oviposition and feeding of two specialist herbivores of spotted knapweed, Centaurea stoebe
}

\author{
Alexandra R. Collins*, Heinz Müller-Schärer \\ University of Fribourg, Ecology and Evolution Department, Chemin du musée 10, Fribourg-1700, Switzerland
}

\section{H I G H L I G H T S}

Agapeta zoegana oviposited significantly more on rosette and one-stem plants.

$2 \times$ plants had significantly greater A. zoegana larval density than $4 \times$ plants.

Significant correlation between the number of larvae infesting plant roots and Centaurea stoebe root diameter.

- Cyphocleonus achates fed more frequently on multiple-stem $4 \times$ plants.

- Arion lusitanicus had a strong feeding preference for younger rosette plants.

\section{G R A P H I C A L A B S T R A C T}

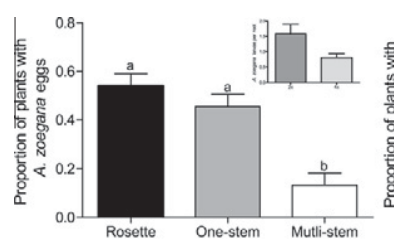

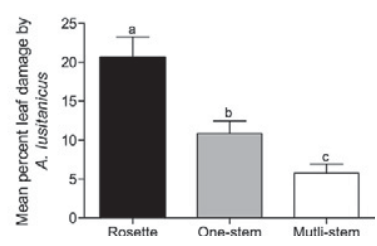

\begin{abstract}
A B S T R A C T
A caged field experiment was used to determine how Centaurea stoebe L. phenostage (rosette, singlestem, multiple-stem) and ploidy level (diploid $=2 \times$ and tetraploid $=4 \times$ ) influence oviposition and feeding of two biological control agents, Agapeta zoegana (Lep.: Cochylidae) and Cyphocleonus achates (Col.: Curculionidae). Ploidy level did not influence oviposition patterns of $A$. zoegana but rosette and one-stem plants had significantly more eggs than multiple-stem $(4 \times)$ plants. Differences in oviposition levels did not translate into differences in larval densities, but $2 \times$ plants (particularly large one-stem plants) had significantly more larvae than $4 \times$ plants. There was a significant positive correlation between numbers of larvae and root diameter. Ploidy level and phenostage both had a significant effect on $C$. achates feeding damage, with adults feeding more frequently on multiple-stem plants. No C. achates larvae were observed when the roots were dissected. Furthermore, the generalist herbivore Arion lusitanicus, naturally present in the garden plots, was predominantly associated with young rosette plants, a stage at which survival rate is acknowledged to be the most important determinant of knapweed density. These results indicate that the combined damage caused by A. zoegana and C. achates, superimposed on damage caused by generalist herbivores in the local community, could provide effective control for $C$. stoebe.
\end{abstract}

\section{Introduction}

Spotted knapweed (Centaurea stoebe L. subsp. micranthos [Gugler] Hayak [Asteraceae]), also identified as Centaurea maculosa

\footnotetext{
* Corresponding author. Fax: +41263009698.

E-mail addresses: robin.collins@unifr.ch (A.R. Collins), heinz.mueller@unifr.ch (H. Müller-Schärer)
}

(Ochsmann, 2000), is native to Europe and has invaded over 3 million ha of the western United States and Canada (Story and Piper, 2001). Introduced in the 1800s, C. stoebe is now common in pastures, rangelands, forests, and roadsides (Story and Piper, 2001). In Europe, $C$. stoebe occurs in two cytotypes, namely diploids $(2 n=18)$ and tetraploids $(2 n=36)$. Only the tetraploid form occurs in North America (Treier et al., 2009). 
Various measures have been implemented in North America to control the spread of $C$. stoebe, including the use of herbicides (Sheley et al., 1998; Jacobs et al., 2000), the alteration of nutrient availability (Herron et al., 2001) and the use of biological control agents (Müller-Schärer and Schroeder, 1993; Story and Piper, 2001; Caesar et al., 2002; Wooley et al., 2011). Insect biological control agents have received particular attention with 13 species released since 1970 (Story and Piper, 2001; Knochel and Seastedt, 2010).

Biological control of $C$. stoebe remains controversial and has been linked, both directly and indirectly, with increasing (Callaway et al., 1999; Marler et al., 1999; Pearson and Callaway, 2008) and reducing its invasive potential (Story et al., 2008; Knochel and Seastedt, 2010). One problem is that environmental variation and ecological interactions often make it difficult to measure the impact of individual phytophage species on the weed in field (Smith and Story, 2003). In order to gain a better understanding of the impact of biological control on C. stoebe it may be useful to study the suite of herbivores (Wooley et al., 2011) and to determine how they impact different life history stages of their host plant (Myers and Risley, 2000). Oviposition and feeding activity of several biological control agents of $C$. stoebe have been shown to be correlated with plant size (Smith and Story, 2003; Knochel and Seastedt, 2010), with insect abundance and damage being greater on large roots than on small roots (Story et al., 2000). As taproot diameter is correlated with plant age (Story et al., 2001), plant phenology may also play a role in oviposition and feeding but this, to our knowledge, has not been tested. Understanding which phenotypic stages (hereafter phenostages) are most likely to be used by insects will be important for the assessment of the overall impact of biological control on the long-term population dynamics of $C$. stoebe and for parameterizing demographic models. Models of the population dynamics of C. stoebe exist (e.g. Jacobs and Sheley, 1998; Myers and Risley, 2000), but none has taken ploidy level and phenostage into account simultaneously.

The two different cytotypes of $C$. stoebe have substantially different life-histories. Tetraploid cytotypes usually have a polycarpic life cycle, forming rosettes and bolting in the first year, while diploid cytotypes tend to have a monocarpic biennial life cycle, forming rosettes in the first year and bolting in the second year (Boggs and Story, 1987; Müller, 1989; Ochsmann, 2000; Španiel et al., 2008; Treier et al., 2009; Henery et al., 2010; Mráz et al., 2010). Both ploidy levels form rosette and single-stem bolting plants but only tetraploids can achieve multiple-stem bolting plants, with the majority producing multiple stems in the years after their first flowering. The polycarpic life cycle of tetraploids assures greater population persistence than diploids (Broz et al., 2009; Treier et al., 2009; Henery et al., 2010; Mráz et al., 2010). Broz et al. (2009) showed that expression of defense-related genes is greater in native $C$. stoebe tetraploids than in diploids and it has been hypothesized that the monocarpic life cycle of diploids (the more abundant cytotype in Europe) has evolved as a response to selection from specialist herbivores (Klinkhamer et al., 1997; MüllerSchärer et al., 2004). Thus, diploids may be more susceptible to herbivory. Testing whether specialist herbivores use diploid plants differently to tetraploid plants, and whether there is a difference in the use of the different phenostages of each ploidy level could be important in understanding the dynamics of the biological control program against $C$. stoebe in North America where only the tetraploid cytotype is currently invasive.

Agapeta zoegana L. (Lepidoptera: Cochylidae) and Cyphocleonus achates Farh. (Coleoptera: Curculionidae) are two of the agents that have been used for biological control of $C$. stroebe in North America (Müller-Schärer and Schroeder, 1993). A. zoegana is a root-feeding moth that was first introduced to Montana in 1984 (Müller et al. 1988; Story et al., 1991) and C. achates is a root-feeding weevil that was first introduced to North America in the late 1980s (Knochel and Seastedt, 2010). A. zoegana adults are short lived (10-14 days) and begin mating on the day of emergence while usually starting ovipositing on the second night (Müller et al., 1988; Story et al., 1991). Females lay between 150-400 eggs which are deposited singly or in groups on the leaves and stems of knapweed plants (Fitzpatrick, 1989). The larvae develop in the root cortex, where they feed beneath a silken web, hibernate as larvae within their mines and emerge as adults between June and September (Müller et al., 1989; Story et al., 1991). C. achates is univoltine with adults emerging over a 2-3 month period starting in late summer (Stinson et al., 1994; Story et al., 1997; Wikeem et al., 1999). Adults usually live between 8 and 15 weeks (Stinson et al., 1994) feeding on C. stoebe leaves and laying eggs in the root or root crown. Larvae feed and pupate in the root over winter, emerging in June and July (Stinson et al., 1994; Corn et al., 2006, 2009; Goodman et al., 2006).

A caged field experiment was used to determine how $C$. stoebe phenostage (rosette, single-stem, multiple-stem) and ploidy level $(2 \times, 4 \times)$ influence the oviposition and feeding of $A$. zoegana and C. achates. We expected that specialist herbivores would lay more eggs on multiple-stem plants than on rosettes which in turn would have fewer larvae. We also anticipated that specialist herbivores would predominantly use $2 \times$ plants, irrespective of the phenostage, because oviposition experiments have shown that diploid plants suffer more leaf damage than tetraploids from adult C. achaetes (Henery et al., personal observation) and that European tetraploids have greater expression than diploids of transcripts related to constitutive defense (Broz et al., 2009). Understanding if phenostage influences insect damage to roots of $C$. stoebe is important because, if insects predominantly use plants of a particular phenostage, there may be limitations on the overall effect of the agents on the target weed (Smith and Story, 2003). Likewise, understanding how ploidy level influences host use patterns in $A$. zoegana and $C$. achates, could be important in achieving effective biological control of $C$. stoebe.

\section{Material and methods}

\subsection{Insect rearing}

Roots containing larvae of $A$. zoegana and $C$ achetes were collected from two sites in Montana, USA: Dittert gardens and Ambrose creek (Table 1). Roots were packed between layers of moistened paper towels in a cardboard box and shipped to the University of Fribourg via the quarantine laboratory at CABI Europe-Switzerland Centre in Delémont. On arrival, the roots were removed from the packaging and placed in a single layer between moistened paper towels in plastic emergence boxes and kept at $23{ }^{\circ} \mathrm{C}$ and 50\% r.h. Boxes were checked daily for emerged adult insects and paper towels were re-moistened as needed. Newly emerged adults of $A$. zoegana were placed in glass vials and were sexed under a dissecting scope before being added to the experimental cages. Newly emerged $C$. achates were added to a small observation arena where their mating behavior could be observed so that gender could be determined.

\subsection{Seed material}

Seed material was selected at random from 144 diploid and tetrapoid populations collected by Treier et al. (2009) in 2005 and Collins (personal observation) in 2010. Seed material was collected from both the native and invasive range and across a range of populations to reduce sampling effects of a specific origin or population. Seeds were sown at four different time intervals in order to achieve the appropriate phenostages of each cytotype for the 
Table 1

Description of collection sites of roots of C. stoebe infested with larvae of Agapeta zoegana and Cyphocleonus achates.

\begin{tabular}{|c|c|c|c|c|c|}
\hline Collection date & Site & Latitude & Longitude & Elevation & Description \\
\hline 8.-10.6.2010 & Diettert Gardens, Missoula, MT & $\mathrm{N} 46^{\circ} 50.518^{\prime}$ & W $113^{\circ} 59.608^{\prime}$ & $990 \mathrm{~m}$ & Ruderal site, dense $C$. stoebe \\
\hline 8.-10.6.2010 & Ambrose Creek Road, Stevensville, MT & N $46^{\circ} 55.907^{\prime}$ & $\mathrm{W} 113^{\circ} 96.700^{\prime}$ & $1128 \mathrm{~m}$ & Dry rangeland, moderate $C$. stoebe cover \\
\hline
\end{tabular}

beginning of the experiment in June, 2010. All seeds were initially sown in $2 \times 2 \mathrm{~cm}$ seed trays and were watered every other day before being transferred to $1 \mathrm{~L}$ pots, with a mixture of 50:50 potting soil (TKS1 Florigard, DE) to sand by weight. To achieve $4 \times$ multiple-stem plants, seeds were sown in May, 2009 and were left to overwinter outside in pots that were buried to a depth of $15 \mathrm{~cm}$, $2 \times$ one-stem plants were sown in October, 2009 and were also left to overwinter, $2 \times$ rosette and $4 \times$ one-stem plants were sown in April, 2010 and were kept in the greenhouse until the beginning of the experiment, and $4 \times$ rosette plants were sown in the greenhouse in May, 2010.

\subsection{Experimental design}

A caged field experiment using two phenostages of diploid plants $(2 \times)$ and three phenostages of tetraploid plants $(4 \times)$ was used to assess how $C$. stoebe phenostage and ploidy level, irrespective of each other, influenced the oviposition and feeding of A. zoegana and C. achates. The five phenostages consisted of: (1) $2 \times$ rosette, (2) $4 \times$ rosette, (3) $2 \times$ one-stem, (4) $4 \times$ one-stem and (5) $4 \times$ multiple-stem, where one-stem refers to only one bolting stem and multiple-stem refers to multiple flowering stems. The experiment took place at the University of Fribourg experimental garden (N 46 47'30", E 7 9'30') from June, 2010 through April, 2011.

The experimental design consisted of nine plots $(2 \mathrm{~m} \times 1 \mathrm{~m})$ with 25 potted plants (five per phenostage) per plot arranged randomly within a $4 \times 8$ grid with a spacing of $20 \mathrm{~cm}$ between pots. All pots were buried to be flush with the soil. Each plot was enclosed using a $2 \mathrm{~m} \times 1 \mathrm{~m} \times 1.5 \mathrm{~m}$ high cage (FOCO, $\mathrm{CH}$ ) fitted with an insect net ( $2 \mathrm{~mm}$ mesh, Spatz, $\mathrm{CH}$ ). Each insect net had a zipper entry so that the plots could be evaluated for oviposition and feeding. Insect nets were secured at the base of the cage with Velcro and were buried $5 \mathrm{~cm}$ in the ground. Measurements of temperature and relative humidity inside and outside two cages over one week using dataloggers (Elpro, Switzerland) showed that differences inside and outside the cages were negligible (on average $1{ }^{\circ} \mathrm{C}$ warmer and $2 \%$ more humid inside cages than outside). A light lux meter showed that the light intensity inside the cages was reduced by $22 \%$ relative to outside. All plots were weeded on a weekly basis for the two weeks of the experiment when the insects were added and oviposition and feeding levels were measured.

Eighteen $A$. zoegana pairs were added to each cage between 5 and 10 July 2010, and 12 individuals of $C$. achates to each cage between 13 and 22 July 2010. The insects were added to the cages as they emerged from the roots in the growth chamber over a period of 5-8 days. All plants were inspected on 15 July 2010 to determine the presence and number of $A$. zoegana eggs. The presence and position of $C$. achates on the different phenostages of $C$. stoebe was determined on 29 July 2010. One month after the initial inspections damage by locally occurring slugs, mainly Arion lusitanicus, was noticed on the plants. To quantify this, the amount of damage caused by $A$. lusitanicus was measured on 10 randomly-selected leaves of each plant using an ordinal ranking system that incorporated the number of damaged leaves and the extent of leaf damage, according to the method used by Lewis et al. (2006), with: $0=$ no discernible herbivore damage; $1=$ minimal damage with no more than approximately $5 \%$ of any leaf damaged; $2=$ minimal damage but with some leaves with $5-10 \%$ of leaf lamina missing or affected; $3=10-50 \%$ damage on multiple leaves, but fewer than half of all leaves affected; and $4=$ at least half of all leaves with $10-50 \%$ damage, and multiple leaves with more than 50\% area missing.

All pots were left to overwinter and in the spring of 2011 (4-11 April 2011) roots were examined for larvae of $A$. zoegana and $C$. achates. Data were also collected on the root diameter $1 \mathrm{~cm}$ below the root crown of all harvested plants. Root diameter of $C$. stoebe is correlated with plant age and measures of plant size (aboveground biomass, numbers of seed heads, and probability of bolting) (Story et al., 2001).

\subsection{Statistical analysis}

Statistical analyses were performed using JMP (Version 8.0.2, SAS Institute, Cary, N.C.). Analyses included generalized linear models, outlier analyses, and analyses of variance (ANOVAs). A standard expected mean squares ANOVA was used for all models with the exception of analyses for herbivory, survivorship, and presence/absence data for which an ordinal logistic (herbivory) and a generalized linear binomial model with logit link (survivorship and presence/absence) were used. ANOVAs including the main effects of plot, ploidy and phenotype were performed for the mean leaf damage per plant to determine if this factor differed systematically. Analyses for herbivory, survivorship and presence/ absence also included the same model effects. Mean leaf damage was log transformed to achieve normality of the residuals.

\section{Results and discussion}

\subsection{Agapeta zoegana}

The oviposition levels of $A$. zoegana did not significantly differ between ploidy levels but did differ significantly between phenostages. Oviposition occurred more frequently and eggs were laid in greater abundance on rosette and one-stem plants than on multiple-stem plants (Table 2, Fig. 1a). Differences in oviposition levels did not translate to increased number of larvae per root when roots were dissected in the spring. A. zoegana density ranged between zero and twelve individuals per taproot with a mean ( \pm SE) of $1.11 \pm 0.14$. There was no significant difference in the number of larvae found per phenostage $\left(F_{2,176}=0.096, p=0.91\right) .2 \times$ plants had significantly more larvae than $4 \times$ plants $\left(F_{1,176}=6.37, p=0.0125\right)$, a trend which persisted when multiple-stem $4 \times$ plants were excluded $\left(F_{1,149}=6.26, p=0.013\right)$. These results are in agreement with (Henery et al. (personal communication) who found that $A$. zoegana did not discriminate significantly between rosette plants of different ploidy level for oviposition. However, in contrast to the findings of (Henery et al. (personal communication) there was a significant ifference in larval densities between ploidy levels. Thus, $4 \times$ plants, due to their greater expression of secondary metabolism- and defense-related transcripts (Broz et al., 2009), may experience greater levels of herbivore resistance than diploids.

There was a significant positive correlation between the taproot diameter and the number of $A$. zoegana larvae per root (Fig. 2). Multiple-stem plants had the greatest taproot diameter $(8.51 \pm 0.051 \mathrm{~mm})$, followed by one-stem $(6.99 \pm 0.019 \mathrm{~mm})$ and rosette plants $(6.07 \pm 0.018 \mathrm{~mm})$. These results are in agreement 
Table 2

ANOVA and regression estimates for oviposition, feeding preference and larval infestation of the two specialist herbivores, Agapeta zoegana and Cyphocleonus achates as well as the feeding preference of the generalist herbivore Arion lusitanicus on the two different ploidy levels ( $2 \times$ and $4 \times$ ) and three different phenostages (rosette (R), one-stem (OS) and multiple-stem (MS)) of Centaurea stoebe.

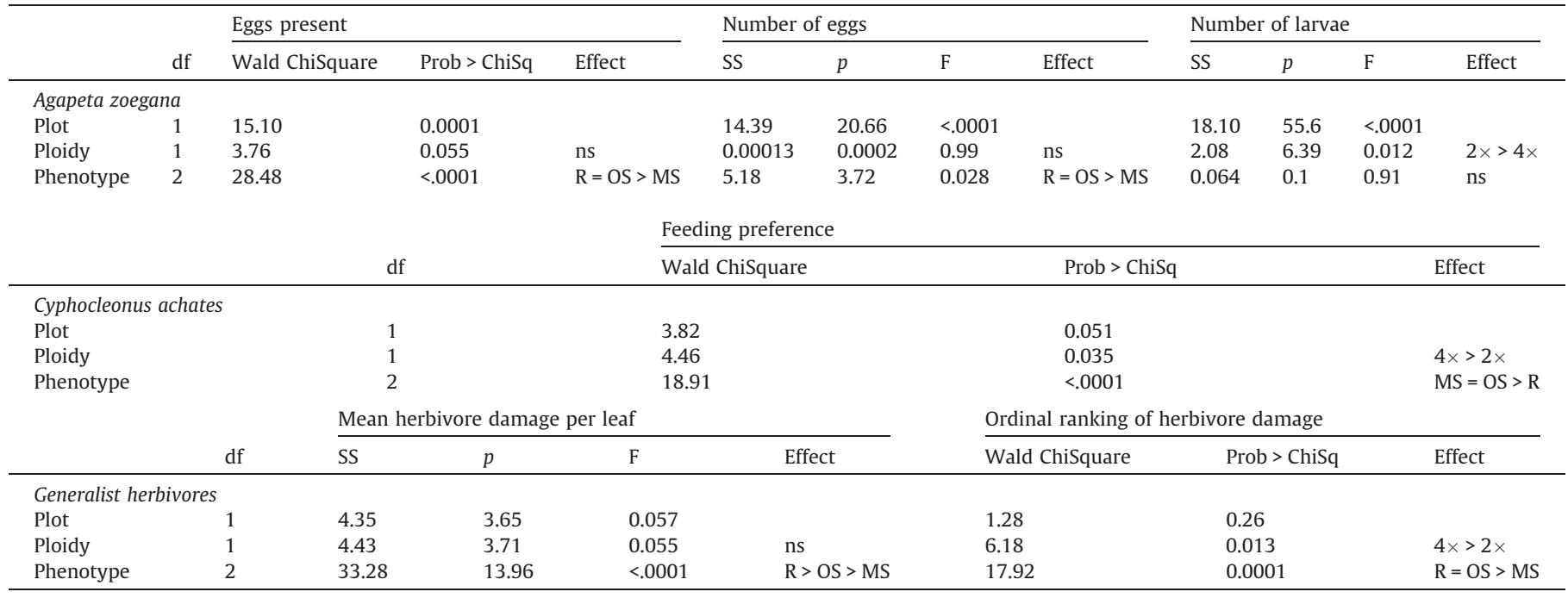
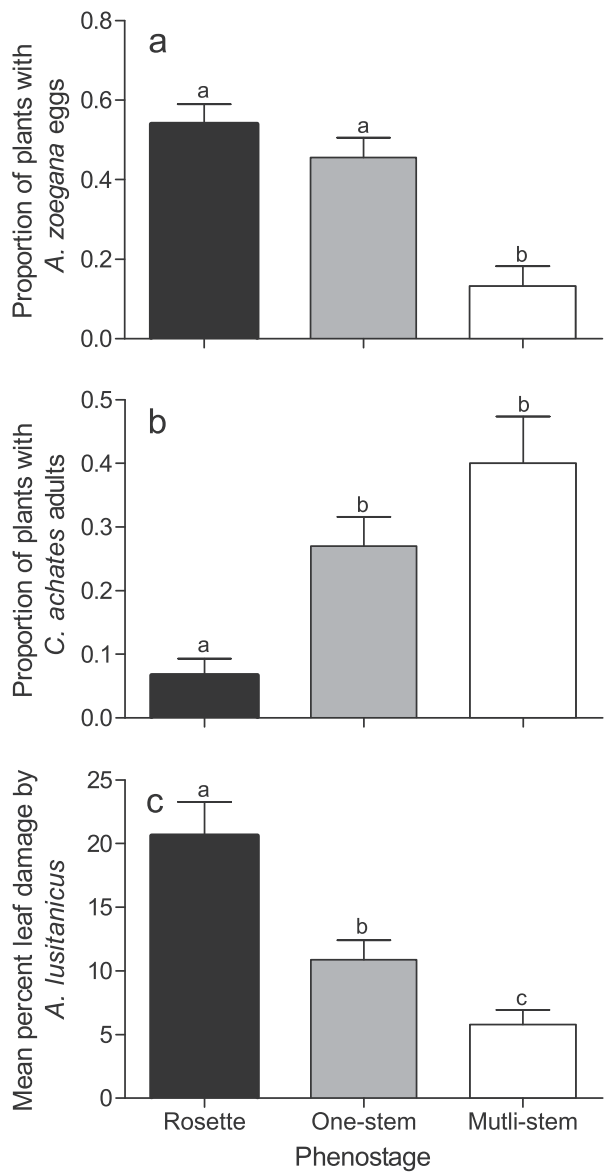

Fig. 1. Mean $( \pm$ SE) of: (a) the proportion of plants with Agapeta zoegana eggs; (b) the proportion of plants with at least one Cyphocleonus achates adult present; and (c) the mean percent leaf damage by Arion lusitanicus, for the three different phenostages of Centaurea stoebe. Rosette refers to plants that do not have a bolting stem, one-stem refers to plants with only one bolting stem and multi-stem refers to plants with multiple flowering stems.

with other studies, which found that $A$. zoegana damage was much greater on larger plants, especially those that were large enough to bolt (Smith and Story, 2003) and that there was no difference in

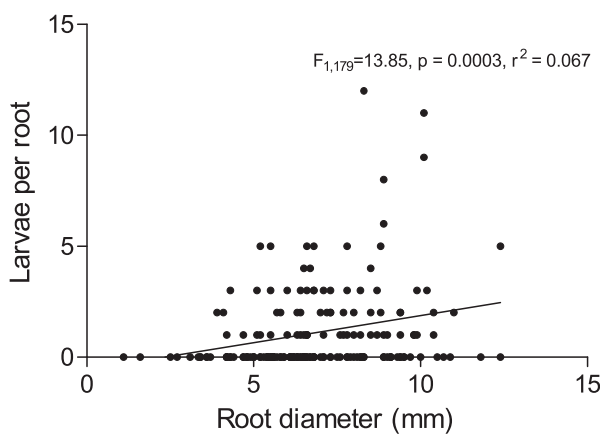

Fig. 2. Linear regression of the root diameter of Centaurea stoebe with the number of Agapeta zoegana larvae found per root.

levels of damage when root diameters were similar (Story et al., 2000). Unexpectedly, mortality was greatest in multiple-stem plants overwinter with $56 \%$ surviving. However, it was difficult to quantify whether this lower survivorship was due to greater damage levels inflicted by $A$. zoegana because dead plant roots were rotten at the time of dissection. Although fewer eggs were laid on multiple-stem plants (cf. above), survival of larvae must have been higher on these plants because they had higher larval densities at the time of dissection.

Despite multiple-stem plants (only $4 \times$ ) having larger roots and larger roots containing more larvae, there was no significant effect of ploidy level (Wald Chi-square $=2.52, p=0.11$ ) or phenostage (Wald Chi-square $=1.11, p=0.57$ ) on whether or not a plant had insects (Table 2). Multiple-stem plants had the lowest number of plants with insects (18\%), followed by one-stem (25\%) and rosette plants (31\%). Despite not being significant, rosette plants had more insects than both other phenostages indicating that greater oviposition on rosette plants may lead to greater numbers of insects on that phenostage. Plant population models indicate that the survival rate of rosette plants is most important for determining knapweed density (Myers and Risley, 2000) and some evidence suggests that immature plants may have reduced survivorship when subject to damage by A. zoegana (Müller et al., 1988; Müller, 1989). Survivorship was lowest in multiple-stem plants, followed by rosette plants and one-stem plants (56\%,67\%, 77\%, respectively) and thus the impact of A. zoegana was greatest on large multiple-stem $4 \times$ plants 
but was still relatively high for rosette plants as well, indicating that $A$. zoegana may provide effective control across phenostages rather than just for large mature plants as has been previously reported (Smith and Story, 2003). Despite lower numbers of larvae on rosette plants, damage by only a few larvae may be enough to lower the survivorship of immature plants due to their smaller root systems (Steinger and Müller, 1992). Furthermore, in populations with high plant density, in which the majority of rosettes remain small, larvae are capable of killing small rosettes and then moving a few centimeters to another knapweed plant to continue feeding (Müller et al., 1988).

\subsection{Cyphocleonus achates}

Ploidy level and phenostage had a significant effect on the presence of $C$. achates which was more prevalent on $4 \times$ plants compared to $2 \times$ plants (Table 2, Fig. 1 b). C. achates was significantly less common on rosette plants than it was on both of the other phenostages. Oviposition of $C$. achates could not be quantified because females dig a tunnel through the soil to the root collar and secure their eggs below the soil surface (Stinson et al., 1994); However, no larvae were found when roots were dissected in April 2011. The reasons for this lack of larvae were not ascertained but C. achates damage has been shown to significantly reduce $C$. stoebe dominance by reducing its population density and abundance (Corn et al., 2006; Jacobs et al., 2006). C. achates weevil density per root has also been shown to have a significant positive relationship with the plant's previous year stem and foliage biomass (Knochel and Seastedt, 2010; Wooley et al., 2011) and thus plant phenostage may be an important determinant for $C$. achates damage, but this will need to be tested further. Still, $C$. achates was present more often on larger $(4 \times)$ multiple-stem plants and it is expected that a greater number of eggs will be laid in hosts that adults (females) find most palatable (Scheirs and De Bruyn, 2002; Henery et al., personal communication). Thus, the predominant feeding preference for $4 \times$ multiple-stem plants is of relevance for biological control of $C$. stoebe in North America as only the $4 \times$ cytotype is currently present and invasive (Treier et al., 2009).

\subsection{Generalist herbivory}

Overall measures of herbivore damage at the end of the 2010 field season revealed that the three phenostages also experienced differential attack by generalist herbivores, specifically by the slug A. lusitanicus. No slug damage was observed when oviposition and feeding of $A$. zoegana and $C$. achates was quantified, so slug herbivory did not influence their interactions with the plants. The ordinal ranking system used to quantify herbivore damage, as well as the mean percent damage per leaf, revealed that rosette plants had the highest herbivory rates by generalist herbivores, followed by onestem and multiple-stem plants (Table 2, Fig. 1c). Ordinal ranking estimates ranged between 0 and 4 , with a mean $( \pm S E)$ of $2.79 \pm 0.097$, indicating $10-50 \%$ damage on multiple leaves. There was no significant difference in herbivore damage between ploidy levels for the mean percent damage measured across 10 randomly selected leaves, but there was a significant effect of ploidy level for the ordinal ranking approach, where $4 \times$ plants experienced significantly greater herbivore damage by generalist herbivores than $2 \times$ plants (Table 2). Thus, generalist herbivores may act in concert with specialist herbivores to reduce $C$. stoebe plant growth, particularly of young $4 \mathrm{x}$ rosette plants.

\section{Conclusions}

Understanding which phenostages and ploidy levels are most likely to be used by herbivores is important for the assessment of herbivore impact, specifically with regard to the direct impact of biological control agents and for predicting the ultimate impact on the population dynamics of the target plant (Smith and Story, 2003). Our results suggest that the combined release of $A$. zoegana and $C$. achates may have a cumulative negative feedback on $C$. stoebe plant fitness as A. zoegana oviposits on younger rosettes (regardless of ploidy level) and infects all phenostages while $C$. achates feeds (and we assume from previous work oviposits) on larger multiple-stem $(4 \times)$ plants. Taken together, the two specialist herbivores may reduce the fitness of both young and old phenostages and thus provide effective control of the weed. Furthermore, generalist herbivores in the local community, such as A. lusitanicus, may also contribute to control, particularly by damaging rosette plants whose survival rate determines knapweed densities (Myers and Risley, 2000). What remains unclear is how damage levels impact the long-term survival and fitness of rosette, one-stem and multiple-stem plants. Future studies should thus measure the reproductive output and survivorship of the pants to build more detailed demographic models that will allow more accurate determination of the long term impact of these biological control agents.

\section{Acknowledgments}

The authors wish to thank R. Naderi, S. Rossinelli, A. Bourqui, N. Imambocus, M. Hahn, J. Schoepfer and A. Bréchon for their help with field work, insect rearing and plant preparation in the greenhouse. Sincere thanks to L. Waller for collecting and shipping the infested roots in MT, USA. This project was funded by the Swiss National Science Foundation (Grant number 31003A_125314) and the National Centre of Competence in Research (NCCR) 'Plant Survival' (both to HMS).

\section{References}

Boggs, K.W., Story, J.M., 1987. The population age structure of spotted knapweed (Centaurea maculosa) in Montana. Weed Science 35, 194-198.

Broz, A.K., Manter, D.K., Bowman, G., Müller-Schärer, H., Vivanco, J.M., 2009. Plant origin and ploidy influence gene expression and life cycle characteristics in an invasive weed. BMC Plant Biology 9, 33.

Caesar, A.J., Campobasso, G., Terragitti, G., 2002. Identification, pathogenicity and comparative virulence of Fusarium spp. associated with insect-damaged, diseased Centaurea spp. in Europe. BioControl 47, 217-229.

Callaway, R.M., DeLuca, T.H., Belliveau, W.M., 1999. Biological-control herbivores may increase competitive ability of the noxious weed Centaurea maculosa. Ecology 80, 1196-1201.

Corn, J.G., Story, J.M., White, L.J., 2006. Impacts of the biological control agent Cyphocleonus achates on spotted knapweed, Centaurea maculosa, in experimental plots. Biological Control 37, 75-81.

Corn, J.G., Story, J.M., White, L.J., 2009. Comparison of larval development and overwintering stages of the spotted knapweed biological control agents Agapeta zoegana (Lepidoptera: Tortricidae) and Cyphocleonus achates (Coleoptera: Curculionidae) in Montana versus Eastern Europe. Environmental Entomology 38, 971-976.

Fitzpatrick, S.M., 1989. A potential collection method for Agapeta zoegana (Lepidoptera: Cochylidae), a knapweed-root-feeding moth. Journal of the Entomological Society of British Columbia 86, 55-62.

Goodman, C.L., Phipps, S.J., Wagner, R.M., Peters, P., Wright, M.K., Nabli, H., Saathoff, S., Vickers, B., Grasela, J.J., McIntosh, A.H., 2006. Growth and development of the knapweed root weevil, Cyphocleonus achates, on a meridic larval diet. Biological Control 36, 238-246.

Henery, M.L., Bowman, G., Mráz, P., Treier, U.A., Gex-Fabry, E., Schaffner, U., MüllerSchärer, H., 2010. Evidence for a combination of pre-adapted traits and rapid adaptive change in the invasive plant Centaurea stoebe. Journal of Ecology 98, $800-813$.

Herron, G.J., Sheley, R.L., Maxwell, B.D., Jacobsen, J.S., 2001. Influence of nutrient availability on the interaction between spotted knapweed and bluebunch wheatgrass. Restoration Ecology 9, 326-331.

Jacobs, J.S., Sheley, R.L., 1998. Observation: life history of spotted knapweed. Journal of Range Management 51, 665-673.

Jacobs, J.S., Sheley, R.L., Story, J.M., 2000. Use of picloram to enhance establishment of Cyphocleonus achates (Coleoptera: Curculionidae). Environmental Entomology 29, 349-354.

Jacobs, J.S., Sing, S.E., Martin, J.M., 2006. Influence of herbivory and competition on invasive weed fitness: observed effects of Cyphocleonus achates (Coleoptera: Curculionidae) and grass-seeding treatments on spotted knapweed performance. Environmental Entomology 35, 1590-1596. 
Klinkhamer, P.G.L., Kubo, T., Iwasa, Y., 1997. Herbivores and the evolution of semelparous perennial life-history of plants. Journal of Evolutionary Biology 10 529-550.

Knochel, D.G., Seastedt, T.R., 2010. Reconciling contradictory findings of herbivore impacts on spotted knapweed (Centaurea stoebe) growth and reproduction. Ecological Applications 20, 1903-1912.

Lewis, K.C. Bazzaz, F.A, Liao, Q Orians, C.M. 2006. Geographic patterns of herbivory and resource allocation to defense, growth and reproduction in an invasive biennial, Alliaria petiolata. Oecologia 148, 384-395.

Marler, M.J., Zabinski, C.A., Callaway, R.M., 1999. Mycorrhizae indirectly enhance competitive effects of an invasive forb on a native bunchgrass. Ecology 80, 1180-1186.

Mráz, P., Bourchier, R., Treier, U., Schaffner, U., Müller-Schärer, H., 2010. Polyploidy in phenotypic space and invasion context: a morphometric study of Centaurea stoebe s.l. International Journal of Plant Sciences 172, 386-402.

Müller, H., 1989. Growth-pattern of diploid and tetraploid spotted knapweed, Centaurea maculosa Lam (Compositae), and effects of the root-mining moth Agapeta zoegana (L) (Lep, Cochylidae). Weed Research 29, 103-111.

Müller, H., Schröder, D., Gassmann, A., 1988. Agapeta-zoegana (L) (Lepidoptera, Cochylidae), a suitable prospect for biological-control of spotted and diffuse knapweed, Centaurea maculosa Monnet de la Marck and Centaurea diffusa Monnet de la Marck, (Compositae) in North-America. Canadian Entomologist $120,109-124$.

Müller, H., Stinson, C.S.A., Marquardt, K., Schröder, D., 1989. The entomofaunas of roots of Centaurea maculosa Lam., C. diffusa Lam. and C. vallesiaca Jordan in Europe: niche separation in space and time. Journal of Applied Entomology 107, 83-95.

Müller-Schärer, H., Schroeder, D., 1993. The biological control of Centaurea spp. in North America: do insects solve the problem? Pesticide Science 37, 343-353.

Müller-Schärer, H., Schaffner, U., Steinger, T., 2004. Evolution in invasive plants: implications for biological control. Trends in Ecology \& Evolution 19, 417-422

Myers, J.H., Risley, C., 2000. Why reduced seed production is not necessarily translated into successful biological weed control. In: Spencer, N.R., (Ed.), International Symposium on Biological Control of Weeds. Montana State University, Bozeman, Montana, USA, pp. 569-581.

Ochsmann, 2000. Morphological und molekularsystemtische Untersuchungen an der Centaurea stoebe L. - Gruppe (Asteraceae-Cardueae) in Europa. Dissertationes Botanicae 324, J. Cramer Verlag, Berlin.

Pearson, D.E., Callaway, R.M., 2008. Weed-biocontrol insects reduce native-plant recruitment through second-order apparent competition. Ecological Applications 18, 1489-1500.

Scheirs, R.L., De Bruyn, L., 2002. Integrating optimal foraging and optimal oviposition theory in plant-insect research. Oikos 96, 187-191.

Sheley, R.L., Jacobs, J.S., Carpinelli, M.F., 1998. Distribution, biology, and management of diffuse knapweed (Centaurea diffusa) and spotted knapweed (Centaurea maculosa). Weed Technology 12, 353-362.
Smith, L., Story, J.M., 2003. Plant size preference of Agapeta zoegana L. (Lepidoptera: Tortricidae), a root-feeding biological control agent of spotted knapweed. Biological Control 26, 270-278.

Španiel, S., Marhold, K., Hodálová, I., Lihová, J., 2008. Diploid and tetraploid cytotypes of Centaurea stoebe (Asteraceae) in Central Europe: morphological differentiation and cytotype distribution patterns. Folia Geobotanica 43, 131158.

Steinger, T., Müller, H., 1992. Physiological and growth responses of Centaurea maculosa (Asteraceae) to root herbivory under varying levels of interspecific plant competition and soil nitrogen availability. Oecologia 91, 141-149.

Stinson, C.S.A., Schroeder, D., Marquardt, K., 1994. Investigations on Cyphocleonus achates (Fahr) (Col-Curculionidae), a potential biological-control agent of spotted knapweed (Centaurea maculosa Lam) and diffuse knapweed (Centaurea diffusa Lam) (Compositae) in North-America. Journal of Applied Entomology 117, 35-50.

Story, J.M., Piper, G.L., 2001. Status of biological control efforts against spotted and diffuse knapweed. In: Smith, L., (Ed.), The First International Knapweed Symposium of the 21st Century. Coeur d' Alene, ID, USA, 2001, pp. 11-17.

Story, J.M., Boggs, K.W., Good, W.R., 1991. 1st Report of the establishment of Agapeta zoegana L. (Lepidoptera, Cochylidae) on spotted knapweed, Centaurea maculosa Lamarck, in the United-States. Canadian Entomology 123, 411-412.

Story, J.M., Good, W.R., White, LJ. 1997. First report of the establishment of Cyphocleonus achates (Fahraeus) (Coleoptera: Curculionidae) on spotted knapweed, Centaurea maculosa Lamarck, in the United States. Canadian Entomology 129, 373-374.

Story, J.M., Good, W.R., White, LJ., Smith, L, 2000. Effects of the interaction of the biocontrol agent Agapeta zoegana L. (Lepidoptera: Cochylidae) and grass competition on spotted knapweed. Biological Control 17, 182-190.

Story, J.M., Smith, L., Good, W.R., 2001. Relationship among growth attributes of spotted knapweed (Centaurea maculosa) in Western Montana. Weed Technology 15, 750-761.

Story, J.M., Smith, L., Corn, J.G., White, L.J., 2008. Influence of seed head-attacking biological control agents on spotted knapweed reproductive potential in western Montana over a 30-year period. Environmental Entomology 37, 510 519.

Treier, U.A., Broennimann, O, Normand, S., Guisan, A., Schaffner, U., Steinger, T. Mueller-Schaerer, H., 2009. Shift in cytotype frequency and niche space in the invasive plant Centaurea maculosa. Ecology 90, 1366-1377.

Wikeem, B.M., Powell, G.W., Sturko, A., 1999. Biology of Cyphocleonus achates (Coleoptera: Curculionidae), propagated for the biological control of knapweeds (Asteraceae). Canadian Entomology 131, 243-250.

Wooley, S.C., Smith, B., King, C., Seastedt, T.R., Knochel, D.G., 2011. The lesser of two weevils: physiological responses of spotted knapweed (Centaurea stoebe) to above- and belowground herbivory by Larinus minutus and Cyphocleonus achates. Biocontrol Science Technology 21, 153-170. 